\title{
THE EFFECT OF POMEGRANATE PEEL AND PISTACHIO HULLS ON PERFORMANCE AND ENTERIC METHANE EMISSIONS IN STRAW-FED LAMBS (Ovis aries L.)
}

\author{
YURTSEVEN, S. ${ }^{1 *}-$ KAYA, Z. ${ }^{1}-$ TAKIM, ${ }^{2}{ }^{2}$ \\ ${ }^{1}$ Faculty of Agriculture, Dept.of Anim. Science, University of Harran, 63000 Şanliurfa, Turkey \\ ${ }^{2}$ Faculty of Veterinary Medicine, University of Harran, 63100 Şanliurfa, Turkey \\ *Corresponding author \\ e-mail: syurtseven2001@yahoo.com; phone: +90-414-318-3474; fax: +90-414-318-3274
}

(Received $10^{\text {th }}$ Sep 2018; accepted $29^{\text {th }}$ Nov 2018)

\begin{abstract}
This trial was conducted to determine the effect of pomegranate peel (PP) and pistachio hulls $(\mathrm{PH})$ added to wheat straw (WS) on some performance parameters and production of some greenhouse gases in female Awassi lambs (Ovis aries L.). This research was conducted in Sanliurfa province in Southeastern Turkey and it was done at Harran University Faculty of Agriculture. Fifteen lambs were used in a completely randomized design with 52 days periods ( 45 days of fattening performance and 7 days of gas measurements) and three treatments: control (90\% concentrate $+10 \%$ WS); PP $(90 \%$ concentrate $+5 \% \mathrm{PP}+5 \% \mathrm{WS})$; and $\mathrm{PH}(90 \%$ concentrate $+5 \% \mathrm{PH}+5 \% \mathrm{WS})$. Emissions of nitrous oxide $\left(\mathrm{N}_{2} \mathrm{O}\right)$ and enteric methane $\left(\mathrm{CH}_{4}\right)$, and carbon dioxide $\left(\mathrm{CO}_{2}\right)$ production were also measured during the last week (7 days). Performance parameters did not change with inclusion of PP and $\mathrm{PH}$ in the diet for 0-6 weeks. However, inclusion of PP decreased feed intake during 0-3 weeks. The $\mathrm{CO}_{2}$ emissions (as $\mathrm{g}$ $\mathrm{day}^{-1} \mathrm{lamb}^{-1}$ and $\mathrm{g} \mathrm{kg}^{-1}$ dry matter intake) significantly increased in the PP and $\mathrm{PH}$ groups, but $\mathrm{CH}_{4}$ emissions did not significantly change. Total $\mathrm{N}_{2} \mathrm{O}\left(\mathrm{g}^{-1}\right.$ day $\left.^{-1} \mathrm{lamb}\right)$ emissions from feces were affected by inclusion of $\mathrm{PH}$ in the diet. The PH supplementation showed a strong tendency for reducing $\mathrm{N}_{2} \mathrm{O}$ emissions from feces of lambs.
\end{abstract}

Keywords: methane, by-product, manure, sheep, tannin

\section{Introduction}

The increase in individual consumption causes the amount of vegetable waste to increase rapidly. An important method of recovery in sustainable vegetable waste management is composting. Another important option is to evaluate wastes such as fruit peel as animal feed. Production of pomegranate and pistachio has increased due to the South Anatolian Project in the Southeastern Anatolia region of Turkey. According to the Turkish Statistics Institution (TUIK, 2016), 144000 tonn of pistachios were produced in Turkey during 2015. Of this, $30 \%$ is produced in Sanliurfa Province, with an average for the last 5 years of 38000-42000 tonn/year (TUIK, 2015). In Sanliurfa, 7 tonnes of soft shells or hulls are produced annually. The pistachio soft hull (PH) is red or burgundy colored and is separated by post-harvest crushing. It is composed of fruit stem, leaf, fruit content, and mesocarp (middle shell) (Shakeri et al., 2014). The PH obtained from the factories also contains some tree leaves.

The PH contains high concentrations of non-structural carbohydrate $(36 \%-40 \%)$, moderate concentrations of crude protein (11.4\%-13\%), 6\% fat, and 30\%-33.3\% neutral detergent fiber - NDF (Shakeri et al., 2013). The PH contains high concentrations of polyphenolic compounds $(7.8 \%)$ and the halves of these compounds are composed of tannins (Shakeri et al., 2013). Therefore PH cannot enter as only one rough feed in ratio. In Sanliurfa, 9600 tonnes of pomegranates are produced per year 
(TUIK, 2016). Since $48 \%$ of the total weight of pomegranate consists of soft crust, 4800 tonnes of these are produced annually. Tannins, which are found in pomegranate seeds and peels (PP) or $\mathrm{PH}$, exhibit inhibitory effects on protein binding and bacterial proliferation and have antimicrobial, antioxidant, and anti-inflammatory effects in digestion both in vivo and in vitro (Adams et al., 2006; Jayaprakasha et al., 2006; Zarei, 2013).

$\mathrm{N}_{2} \mathrm{O}$ is a dangerous greenhouse gas and expected to increase by $35-60 \%$ by 2030 with an increase in demand for meat and dairy products (IPCC, 2007). PP or PH containing tannins may improve $\mathrm{N}$ utilization efficiency and thereby decrease the $\mathrm{N}$ content of manure, which, in turn, may affect $\mathrm{N}_{2} \mathrm{O}$ emissions because less $\mathrm{N}$ is available to the denitrifying bacteria that use the manure as substrate.

The addition of saponins from PP can thus modify the $\mathrm{C}$ and $\mathrm{N}$ contents of sheep manure. Sheep (Ovis aries L.) produce $8 \mathrm{~kg}$ of enteric methane $\left(\mathrm{CH}_{4}\right)$ gas per animal per year (Broucek, 2014) and any $\mathrm{CH}_{4}$ reduction potential due to tannins suppressing $\mathrm{CH}_{4}$-producing microorganisms in the rumen will be determined in vivo. $\mathrm{PP}$ and $\mathrm{PH}$ can also provide an advantage especially for lowering the higher fiber concentration that comes with the wheat straw. This study will also investigate the potential of PP and PH as forage sources to reduce the use of wheat straw.

\section{Materials and methods}

\section{Animal and feed material}

The study was conducted between December and November at Sanliurfa province in the Southeast Anatolian Region of Turkey, which lies on $37^{\circ} 9^{\prime} 32.9364$ latitude (N) and $38^{\circ} 47^{\prime} 48.8724$ longitude (W). Research on animals was conducted according to the institutional committee on animal use. Ethics committee approval was obtained from DOLLVET animal vaccine production center (DOLLVET-HADYEK-2015/01). The experiment was carried out on 6-month-old female Awassi lambs (Ovis aries L.) for 52 days: 45 days of fattening performance and 7 days of gas measurements. The total of 15 lambs was divided into three groups (Table 1) with five individual compartments of similar individual weight $(29.13 \pm 3.18 \mathrm{~kg})$ and age (Fig. 1).

Table 1. Experimental groups

\begin{tabular}{c|c|c}
\hline Groups & Concentrate & Forage \\
\hline 1-Control & $90(\%)$ & $10(\%)$ straw \\
2-Pomegranate peel (PP) & $90(\%)$ & $5(\%)$ straw $+5(\%)$ pomegranate peel \\
3-Pistachio hulls $(\mathrm{PH})^{1}$ & $90(\%)$ & $5(\%)$ straw $+3(\%)$ pistachio hulls $+2(\%)$ \\
pistachio hulls and leaves
\end{tabular}

1; PH in the study consists of a mixture of pure pistachio hull and some leafy fraction

The rations were given to the animals as mixed forage and concentrated feed total mixed ration (TMR; Table 2). The rate of WS used in the control ration was 10\%; PP and PH replaced half of the WS to form the other feeding groups. Dry PP containing some crushed grain was obtained by drying in the sun at $40{ }^{\circ} \mathrm{C}$ for 1 week.

The $\mathrm{PH}$ used in the study consisted of pure soft burgundy fraction and a small amount of pistachio tree leaves. Dry PP and WS $(3-5 \mathrm{~cm})$ were crushed; and the PH was used without treatment (Table 3). In order not to stress the lambs, the feeding was 


$$
\text { - } 307 \text { - }
$$

done by adding every morning during the week as a little more than the maximum amount that they could consume daily. At the end of each week, the remaining feed was weighed and subtracted from the feed added for one week and divided into 7 days. Thus, daily feed consumption was found.

Table 2. Contents of total mixed ration (TMR) used in the lamb growth diet in the experiment ( $\mathrm{g} / \mathrm{kg}$ as fed basis)

\begin{tabular}{|c|c|c|c|}
\hline Feed ingredient & Control & $\mathbf{P P}^{1}$ & PH \\
\hline Barley & 216.9 & 216.9 & 216.9 \\
\hline Corn & 266.58 & 266.58 & 266.58 \\
\hline Soybean meal & 165.78 & 165.78 & 165.78 \\
\hline Wheat bran & 225 & 225 & 225 \\
\hline Limestone & 19.44 & 19.44 & 19.44 \\
\hline Salt & 5.4 & 5.4 & 5.4 \\
\hline Vit + min.pre. ${ }^{2}$ & 0.9 & 0.9 & 0.9 \\
\hline Wheat straw & 100 & 50 & 50 \\
\hline PP & 0 & 50 & 0 \\
\hline PH & 0 & 0 & 50 \\
\hline Total & 1000 & 1000 & 1000 \\
\hline \multicolumn{4}{|c|}{ Nutrient values (as fed basis) } \\
\hline Dry matter $(\%)$ & 89.7 & 89.4 & 89.6 \\
\hline $\operatorname{ME}(\mathrm{Mcal} / \mathrm{kg})$ & 2.4 & 2.4 & 2.4 \\
\hline Crude protein (\%) & 16 & 15.9 & 15.9 \\
\hline Ether extract $(\%)$ & 3 & 3 & 3 \\
\hline Crude fiber $(\%)$ & 9.7 & 9.25 & 8.4 \\
\hline $\operatorname{ADF}(\%)$ & 11.6 & 11.8 & 10.2 \\
\hline $\operatorname{NDF}(\%)$ & 26.8 & 25.3 & 24.4 \\
\hline Ash (\%) & 4.08 & 4.2 & 4.1 \\
\hline Calcium (\%) & 0.87 & 0.86 & 0.86 \\
\hline Phosphorus (\%) & 0.6 & 0.59 & 0.59 \\
\hline Sodium (\%) & 0.31 & 0.3 & 0.32 \\
\hline Tannin $(\mathrm{mg} \text { eq } / \mathrm{g})^{3}$ & 38.25 & 68.44 & 79.36 \\
\hline Saponin $(\mathrm{mg} / \mathrm{g})^{3}$ & 15.8 & 54.71 & 15.6 \\
\hline
\end{tabular}

${ }^{1}$; PP, pomegranate peel; PH, Pistachio hulls. ME, methabolic energy, ${ }^{2} ; 1 \mathrm{~kg}$ vitamin mineral mixture: 15.000 IU vitamin A, $25 \mathrm{mg}$ Vit E, 4000 IU Vit D3; Trace minerals: Fe: $50 \mathrm{mg}$, Co: $0.1 \mathrm{mg}$, Mn: 50 $\mathrm{mg}$, Se: $0.2 \mathrm{mg}$, I: $0.8 \mathrm{mg}$, Cu: $10 \mathrm{mg}, \mathrm{Zn}: 50 \mathrm{mg},{ }^{3}$; Dry matter bases

Table 3. Nutritional values of plant byproducts used in the experiment (as fed basis)

\begin{tabular}{c|c|c|c|c}
\hline & PP $^{1}$ & Pistachio hulls & Pistachio hulls and leaves & Wheat straw \\
\hline Dry matter (\%) & 91.00 & 92.00 & 92.00 & 91 \\
Crude ash (\%) & 8.00 & 9.00 & 8.50 & 8.0 \\
Crude protein (\%) & 5.83 & 7.03 & 4.40 & 8.2 \\
\hline ADF (\%) & 48.50 & 20.19 & 20.6 & 52 \\
NDF (\%) & 55.20 & 24.39 & 28.2 & 80 \\
\hline
\end{tabular}

${ }^{1}$; PP, pomegranate peel; ADF, acid detergent fiber; NDF, neutral detergent fiber 


$$
\text { - } 308 \text { - }
$$

\section{$\mathrm{CH}_{4}$, carbon dioxide $\left(\mathrm{CO}_{2}\right)$ and nitrous oxide $\left(\mathrm{N}_{2} \mathrm{O}\right)$ measurements in respiration chamber}

The enteric $\mathrm{CH}_{4}$ measurement was initiated in lambs adapted to their feed for 45 days. For this purpose, an isolated container (dimensions $2 \times 2 \times 2 \mathrm{~m}$ ) with two chambers was turned into a respiration chamber with controlled air inlets and outlets (Fig. 1).

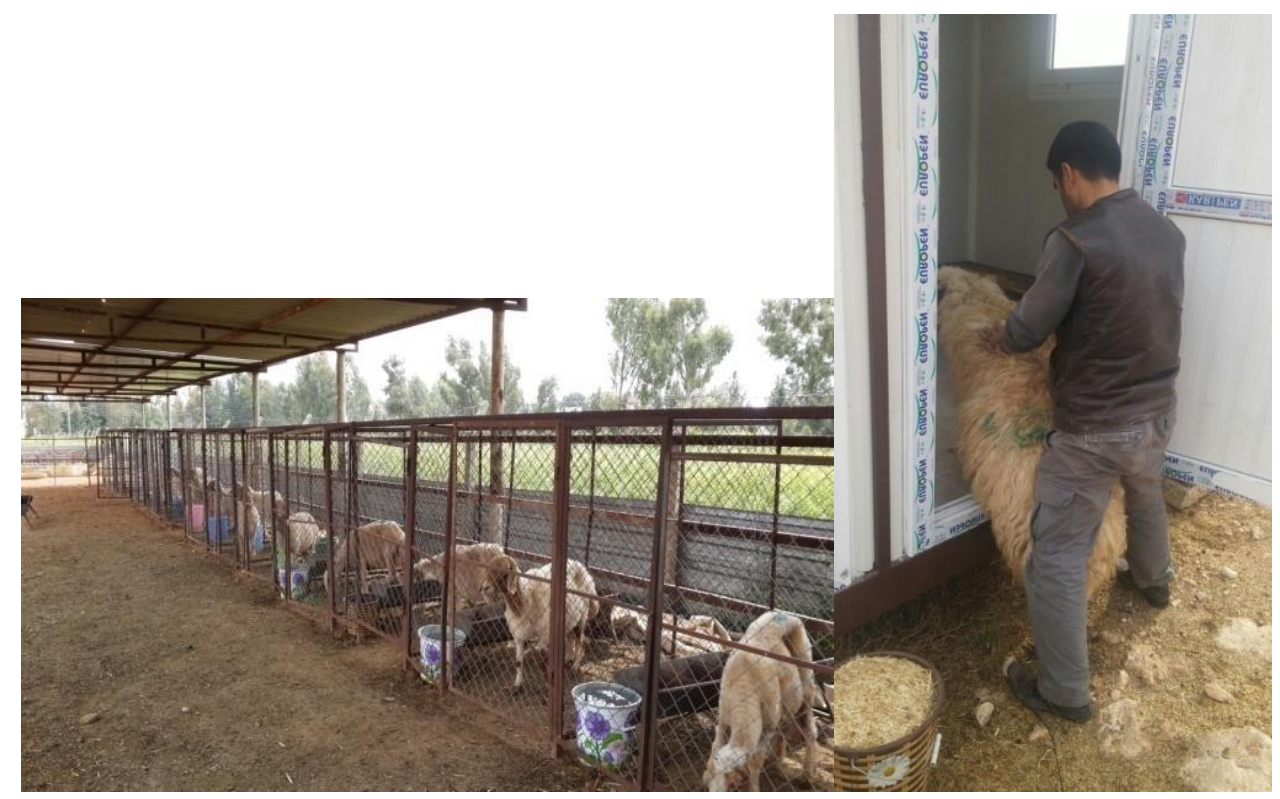

Figure 1. Individual compartments and respiration chamber

As there was herd/flock of psychology in the lambs, the rooms were arranged with glass windows. The lambs were able to see each other and reduce stress. In addition, they were left in the room for 24 hours in order to reduce the effect of stress and acclimate to the room environment. Two pipes (as inlet and outlet) were each attached to a fan of approximately $0.25 \mathrm{~m}^{3} / \mathrm{sec}$. air supply capacity in each room. The pipes were cylindrical chimneys with a diameter of $10 \mathrm{~cm}$ and a length of $30 \mathrm{~cm}$ and fresh air was pumped into each room with a fan in the inlet pipe and extracted by another fan in the outlet pipe. Gas emissions were measured by subtracting the concentrations of the gases in the air entering and leaving the chamber.

After the lambs were taken to the room, the fans were activated and the temperature and humidity inside and outside the room were recorded. For each animal, air samples were taken with syringes at least 5-6 times for both inlet and outlet from fan cylinders during daylight and were immediately sealed with an airtight cover. After the end of day light, the sampling was continued and samples were taken every 2 hours. During the gas measurement period, the lambs stayed in the respiratory room with feeders for 23 hours from $08.30 \mathrm{~h}$ in the morning until 07:30 $\mathrm{h}$ the following morning.

At intervals of $1 \mathrm{~h}$, the rooms were ventilated and the stool and urine of the previous lamb were removed. Gases were identified with gas chromatography (GC) on sampled syringe tubes as ppm for entering and exiting air (SRI InstrumentsEuropean Greenhouse GC System ${ }^{\circledR}$ - Germany). A 3-m Hayesep D packed column 
was used for $\mathrm{CO}_{2}, \mathrm{CH}_{4}$, and $\mathrm{N}_{2} \mathrm{O}$ diagnosis. Operating conditions for GC: injector temperature was $95^{\circ} \mathrm{C}$, column temperature was $85^{\circ} \mathrm{C}$, and detector temperature was $320^{\circ} \mathrm{C}-350^{\circ} \mathrm{C}$.

Gas concentrations were calculated using the following formula (Petrucci et al., 2010) in the incoming and outgoing air (Eq. 1):

$$
\mathrm{CO}_{2}, \mathrm{CH}_{4}, \mathrm{~N}_{2} \mathrm{O}=\left\lfloor\mathrm{C} \cdot \mathrm{Ma} \frac{\mathrm{P}}{R T} \mathrm{~V} \cdot \mathrm{A}\right\rfloor
$$

$\mathrm{CH}_{4}, \mathrm{CO}_{2}$ and $\mathrm{N}_{2} \mathrm{O}$ in $\mathrm{g} / \mathrm{sec}, \mathrm{C}$ is fresh air entering the room and gas concentration in the leaving air (ppm), $M a$ is gas molecular weight $(\mathrm{g} / \mathrm{mol}), P$ is barometric air pressure $(\mathrm{Pa}), V$ is entering and leaving air velocity $(\mathrm{m} / \mathrm{sec}), R$ is the universal gas constant $\left(8.31 \mathrm{~J} / \mathrm{molK}^{1}\right), T$ is ambient temperature, and $A$ is area of a cross-section of the cylindrical chamber $\left(0.0250 \mathrm{~m}^{2}\right)$.

\section{Chemical analyses}

Dry matter, crude ash, and crude protein analyses of feeds used in the trials were performed according to the classical AOAC (1998) procedures. Fiber analyses (acid detergent fiber - ADF and NDF) were performed with an ANKOM Fiber Analyzer according to Van Soest et al. (1991).

\section{Tannin analysis}

A standard tannin analysis curve was prepared according to Makkar et al. (1995) and used to calculate tannin contents (Table 4). To prepare the standard curve, 2, 4, 6, 8,10 , and $12 \mu \mathrm{g} / \mathrm{ml}$ pure tannin was placed in the test tubes, $500 \mu \mathrm{l}$ of Folin Ciocalteau separator was added and mixed for 3 min. After addition of $2500 \mu \mathrm{l}$ of $\mathrm{Na}_{2} \mathrm{CO}_{3}$, the tubes were shaken for $60 \mathrm{~min}$, and absorbance measured at $725 \mathrm{~nm}$. The regression equation obtained from reading values revealed tannin concentrations of the feed samples.

The feed samples milled to $1 \mathrm{~mm}$ were treated with the condensed tannin (CT) solution. For the CT solution, $0.05 \mathrm{~g}$ of $\mathrm{FeSO}_{4}$ was added to the tube and $0.015 \mathrm{~g}$ of ground sample was added. Then $2 \mathrm{ml}$ of $0.55 \mathrm{M}$ butanol- $\mathrm{HCl}$ reagent was added to each tube and then mixed with a vortex. The test tube was tightly sealed, kept at 97$100{ }^{\circ} \mathrm{C}$ for $1 \mathrm{~h}$, and absorbance values measured at $580 \mathrm{~nm}$ (Karaogul, 2011).

Table 4. Determination of condensed tannin value from standard curve

\begin{tabular}{|c|c|c|c|c|c|}
\hline Items & $\begin{array}{l}\text { Standard } \\
\text { compound }\end{array}$ & $\begin{array}{c}\text { Calibration } \\
\text { equation }\end{array}$ & $\mathbf{R}^{2}$ & $\begin{array}{c}\mathrm{LOD} / \mathrm{LOQ}^{3} \\
\left(\mu \mathrm{g} \mathrm{I}^{-1}\right)\end{array}$ & $\begin{array}{c}Q^{4}(\mathrm{mg} \text { equivalent } \\
\mathrm{g}^{-1} \text { dry matter) }\end{array}$ \\
\hline Wheat straw & Tannic acid & \multirow{4}{*}{$\begin{array}{c}\mathrm{Y}= \\
0.053 \times+0.0067\end{array}$} & \multirow{4}{*}{0.98} & \multirow{4}{*}{$0-12$} & $35.59 \pm 0.74$ \\
\hline $\mathrm{PP}^{1}$ & Tannic acid & & & & $103.52 \pm 1.65$ \\
\hline $\begin{array}{l}\text { Pistachio pure } \\
\text { hulls }\end{array}$ & Tannic acid & & & & $173.96 \pm 2.12$ \\
\hline $\begin{array}{l}\text { Pistachio hull and } \\
\text { leaf (PH) }{ }^{2}\end{array}$ & Tannic acid & & & & $89.05 \pm 0.57$ \\
\hline
\end{tabular}

${ }^{1} ; \mathrm{PP}$, pomegranate peel, ${ }^{2} ; \mathrm{PH}$, consists of pure soft burgundy fraction and a fraction containing a quantity of pistachio tree leaves, ${ }^{3}$; LOD/LOQ: Limit of detection/Limit of quantification, ${ }^{4}$; Quantification 


$$
\text { - } 310 \text { - }
$$

\section{Statistical analyses}

Performance data were analyzed in the One-Way ANOVA procedure according to the experimental design of the three-group randomized design and the treatment combinations were compared with the Duncan's test using SPSS. As for gas emission values, the data were statistically analyzed with Levene's test and Shapiro Wilk test for equality of variances and the normality assumption, respectively $(\mathrm{P}<0.05)$. Then, these data were analyzed by using Kruskal Wallis H test (SPSS, Version 22, 2013) and presented with median and IQR values (interquartile range) in Table 5.

Table 5. Non-parametric results of gas emission values

\begin{tabular}{c|c|c|c|c|c|c}
\hline Groups & $\begin{array}{c}\text { Emission } \\
\text { (g/day lamb) }\end{array}$ & Means & Standard deviation & Median & IQR $^{(2)}$ & P-value \\
\hline Control & & 46.87 & 26.67 & 45.26 & - & \\
$\mathrm{PP}^{1}$ & $\mathrm{CH}_{4}$ & 36.79 & 13.71 & 34.06 & 16.48 & 0.21 \\
$\mathrm{PH}^{1}$ & & 18.72 & 22.03 & 11.40 & 36.36 & \\
\hline $\mathrm{Control}$ & & 514.43 & 50.9 & 514.96 & 412.97 & \\
$\mathrm{PP}$ & $\mathrm{CO}_{2}$ & 1079.90 & 290.6 & 994.34 & 924.79 & 0.04 \\
$\mathrm{PH}$ & & 700.53 & 91.91 & 714.25 & - & \\
\hline $\mathrm{Control}$ & & 186.25 & 56.84 & 186.25 & - & \\
$\mathrm{PP}$ & $\mathrm{N}_{2} \mathrm{O}$ & 182.36 & 108.42 & 166.86 & 206.93 & 0.05 \\
$\mathrm{PH}$ & & 59.26 & 21.99 & 56.25 & 43.56 & \\
\hline
\end{tabular}

1; PP, pomegranate peel; PH, pistachio hulls, ${ }^{2}$; IQR, interquartile range: quarter value width, the third quadrant and the first quadrant range of an ordered data array

\section{Results}

There was no significant difference during the 0-6 week periods of the experiment in terms of the data on the effects of PP and PH additions on feed consumption, live weight change (Fig. 2), and feed conversion ratio (Table 6).

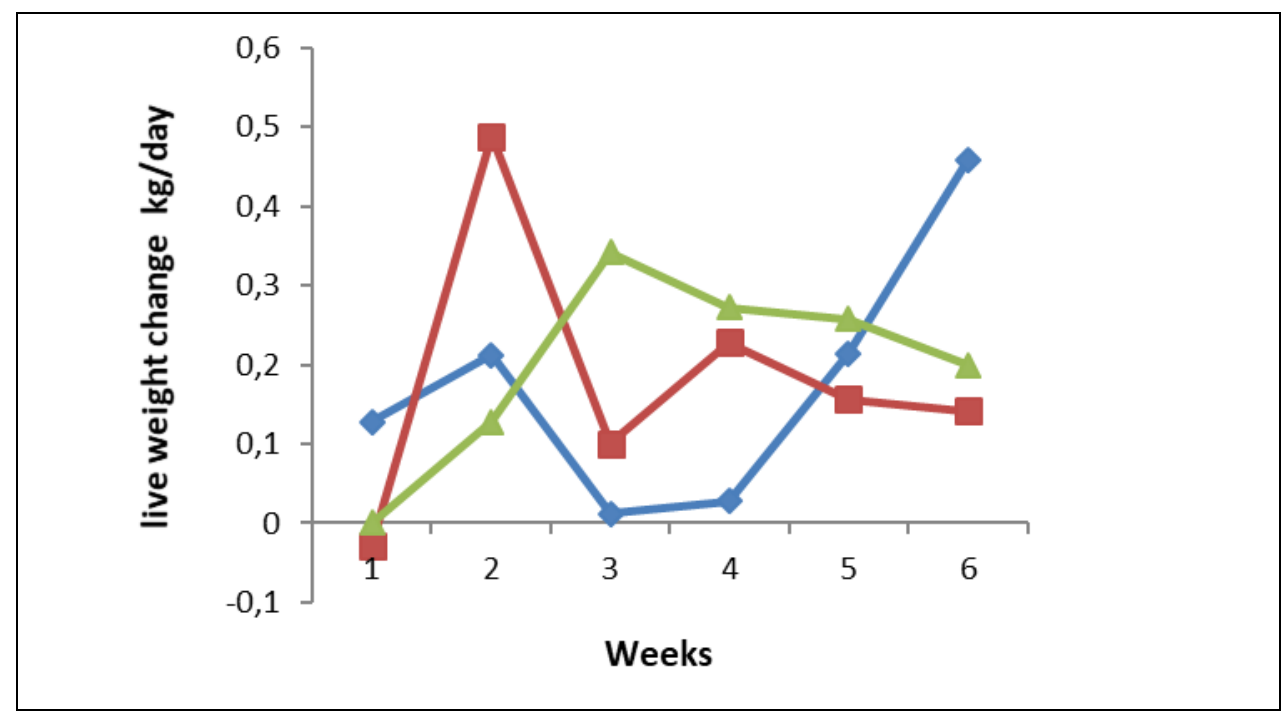

Figure 2. The time dependent changes in live weight gain/change in experimental groups 


$$
-311 \text { - }
$$

Table 6. Means of performance data in the experimental groups during the first half and the last half of the trial

\begin{tabular}{c|c|c|c|c|c|c}
\hline & Weeks & Control & PP $^{\mathbf{1}}$ & $\mathbf{P H}^{\mathbf{2}}$ & $\mathbf{S E M}^{\mathbf{3}}$ & P-value $^{*}$ \\
\cline { 2 - 7 } Feed consumption (kg/day as & $0-3$ & $1.93 \mathrm{~b}^{4}$ & $1.83 \mathrm{a}$ & $1.93 \mathrm{~b}$ & 0.02 & 0.02 \\
fed) & $3-6$ & 1.90 & 1.94 & 1.97 & 0.03 & 0.27 \\
& $0-6$ & 1.92 & 1.88 & 1.95 & 0.02 & 0.16 \\
\hline \multirow{2}{*}{ Metabolic energy intake } & $0-3$ & $4.60 \mathrm{~b}$ & $4.41 \mathrm{a}$ & $4.62 \mathrm{~b}$ & 0.04 & 0.02 \\
(Mcal/day) & $3-6$ & 4.57 & 4.62 & 4.73 & 0.06 & 0.25 \\
& $0-6$ & 4.61 & 4.55 & 4.68 & 0.05 & 0.16 \\
\hline \multirow{2}{*}{ Live weight gain (g/day) } & $0-3$ & 120 & 220 & 158 & 68.8 & 0.63 \\
& $3-6$ & 234 & 176 & 244 & 26.1 & 0.22 \\
& $0-6$ & 213 & 182 & 202 & 29.8 & 0.81 \\
\hline \multirow{3}{*}{ Feed conversion ratio } & $0-3$ & 8.19 & 12.95 & 15.18 & 4.59 & 0.56 \\
& $3-6$ & 8.30 & 13.06 & 8.40 & 1.26 & 0.06 \\
\hline
\end{tabular}

${ }^{1}$; PP, pomegranate peel, ${ }^{2}$; PH, pistachio hulls, ${ }^{3}$; SEM, standard error of the mean, ${ }^{4}$; Different letters show significant differences between the columns in the same row

Except for the first week of the experiment, no significant differences in these performance values were observed. In the first 3 weeks of the experiment $(\mathrm{P}<0.05)$, feed consumption was lower in lambs receiving PP (Fig. 3) in terms of trial averages, and similar live weight gains were obtained in all groups $(\mathrm{P}>0.05)$.

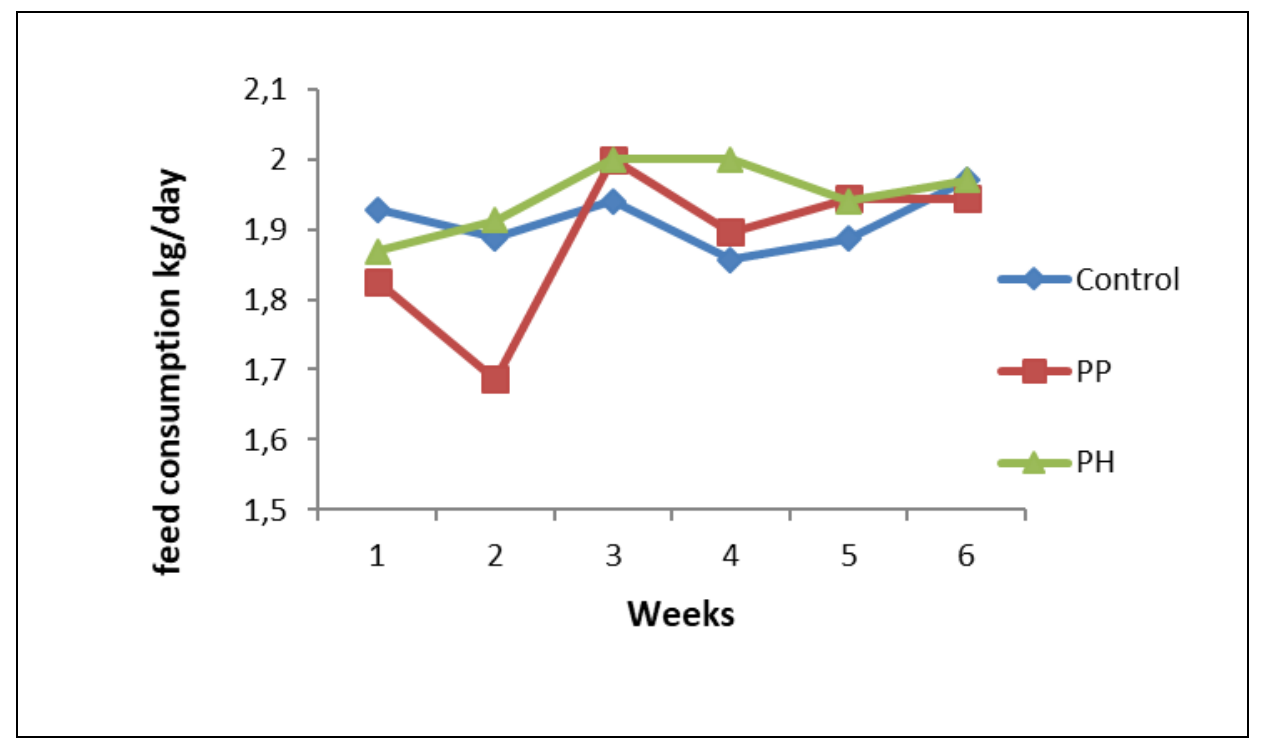

Figure 3. The time dependent changes in feed consumption in experimental groups

Energy consumption was similar throughout the trial in all groups, except during the first weeks $(\mathrm{P}<0.05)$. The $\mathrm{CH}_{4}$ emissions were similar in all groups, but with a decreasing trend for $\mathrm{PP}$ and $\mathrm{PH}$ groups $(\mathrm{P}=0.07)$. However, carbon emissions were higher in the $\mathrm{PP}$ and $\mathrm{PH}$ groups $(\mathrm{P}<0.05$; Tables 5 and 7$)$. The $\mathrm{N}_{2} \mathrm{O}$ emission $(\mathrm{g} /$ day $\left.l^{a m b} b^{1}\right)$ in the $\mathrm{PH}$ group was lower than in the control and $\mathrm{PP}$ group $(\mathrm{P}=0.05$; Fig. 4). 


$$
\text { - } 312 \text { - }
$$

Table 7. Gas emission values according to daily dry matter consumption

\begin{tabular}{c|c|c|c|c|c}
\hline & Control & PP $^{\mathbf{1}}$ & PH $^{\mathbf{1}}$ & SEM $^{(2)}$ & P-value \\
\cline { 2 - 6 } $\mathrm{CH}_{4}$ (g/kg DMI) & 24.42 & 19.74 & 9.56 & 5.65 & 0.07 \\
$\mathrm{CO}_{2}$ (g/kg DMI) & $268.13 \mathrm{a},{ }^{3}$ & $578.88 \mathrm{~b}$ & $359.31 \mathrm{a}$ & 70.60 & $\mathbf{0 . 0 3}$ \\
$\mathrm{N}_{2} \mathrm{O}(\mathrm{g} / \mathrm{kg}$ DMI) & $100.07 \mathrm{~b}$ & $98.62 \mathrm{~b}$ & $25.97 \mathrm{a}$ & 34.85 & $\mathbf{0 . 0 3}$ \\
\hline
\end{tabular}

1; PP, pomegranate peel; PH, pistachio hulls; DMI, dry matter intake, ${ }^{2}$; SEM, standard error of the mean, ${ }^{3}$; Different letters show significant differences between the columns in the same row

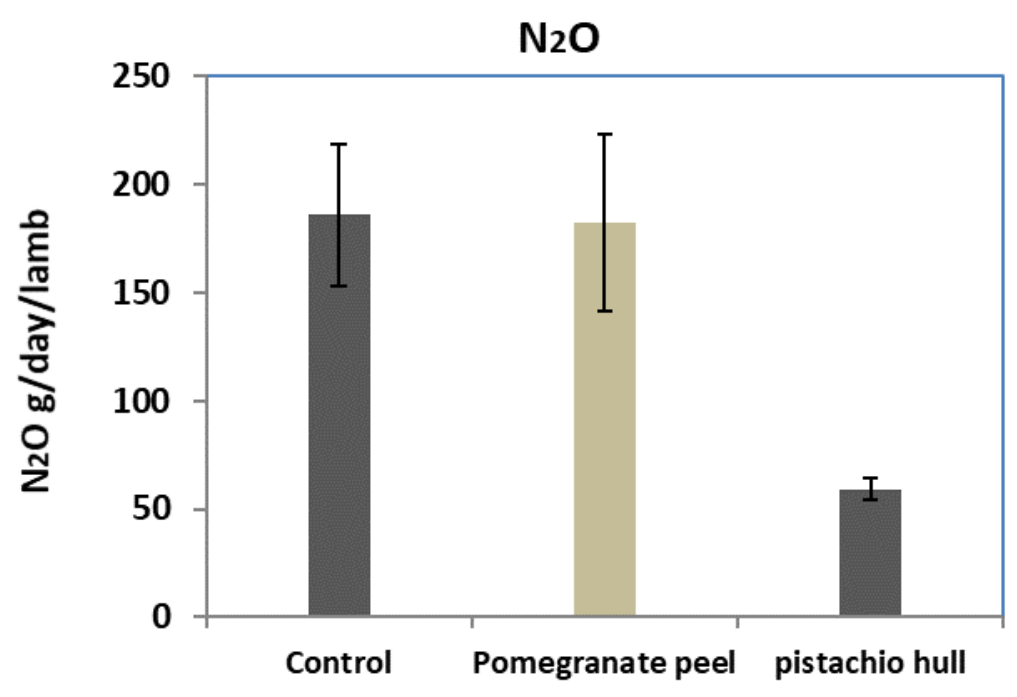

Figure 4. The changes in $\mathrm{N}_{2} \mathrm{O}$ emission levels among groups

\section{Discussion}

Within the first 3 weeks of the experiment, PP negatively affected feed consumption. This negative effect lasted 3 weeks and became less pronounced during the later weeks of the experiment (Figs. 2 and 3) probably due to adaptation to the taste of PP. Provenza (1995) suggests that negative feedback responses diminish over time depending on the negative factor.

The results we obtained were consistent with the results reported by Ghaffari et al. (2014), who feed Afshari and Balouchi male lambs with 30\% PH and did not observe any change in feed intake. The CT concentration in some plants did not limit feed consumption at $50 \mathrm{~g} / \mathrm{kg}$ dry matter (DM) (Barry and McNabb, 1999). However, Bhatta et al. (2002) found that consumption was reduced at CT concentrations above $60 \mathrm{~g} / \mathrm{kg}$. In our study, CT at $90.53 \mathrm{~g} / \mathrm{kg}$ concentrations in the $\mathrm{PH}$ groups did not cause a significant decrease in feed consumption except during the first weeks - this may be due to the difference in plant species. Consistent with our findings, Addisu et al (2016) reported that low or moderate concentrations of CT (20-45 mg equivalent/g DM) in feed stuffs did not affect feed consumption. According to Villalba and Provenza (2000), feed consumption of lambs can improve if a low-quality feed is associated with a nutrient. In our study, TMR was preferred in the first 3 weeks in PH groups due to 
higher protein concentration of PH than PP. However, it is also possible that the higher saponin content in PP groups may cause fluctuations in feed consumption.

The tendency to similar live weight gain in all groups can be attributed to an internal mechanism related to lambs, but the inclusion of PP as half of the forage had a clear negative effect on the lambs. Abarghuei et al. (2013) suggest that PP contains high concentrations of saponin which reduces protein digestibility due to negative effects on digestion, and decreases feed consumption by reducing the palatability. Compared to $\mathrm{PH}$, the lambs reacted more negatively to the PP, indicating that feeds such as pomegranate are more problematic in terms of taste. Kotsampasi et al. (2014) stated that the addition of PP to the TMR at concentrations of 0,120 , and $240 \mathrm{~g} / \mathrm{kg}$ did not significantly affect live weight, live weight gain, DM consumption, and feed utilization. Norouzian and Ghiasi (2012) found that PH substituted for up to 30\% of forage did not significantly change the performance values of lambs, showed no adverse effects, and could be used a part of forage in lamb fattening. However, PP was tolerated by lambs in later periods of the current study.

The consumption values obtained in our study showed that the CT content of PH was less unappealing for the lambs. According to Sadq et al. (2016), CT has a less reducing effect on digestion and voluntary feed intake. When considering feed consumption, lambs need some time to become accustomed to PH and PP feed. Shabtay et al. (2008) found that fresh $\mathrm{PH}$ linearly increased feed consumption and was accompanied by an increased live weight gain - the introduction of tannin-rich PH up to $20 \%$ of the ration had positive effects on fattening performance with no harmful effect.

In our study, addition of $\mathrm{PP}$ and $\mathrm{PH}$ did not significantly affect emissions of enteric $\mathrm{CH}_{4}$ but there was a declining trend for $\mathrm{PP}$ and $\mathrm{PH}$ groups in $\mathrm{CH}_{4}$ emission values when calculated according to $\mathrm{kg}$ feed intake $(\mathrm{P}=0.07)$. The $\mathrm{CH}_{4}$ was of enteric origin and $\mathrm{CO}_{2}$ both enteric and respiratory, because feces in an open environment are not an important source of $\mathrm{CH}_{4}$ and $\mathrm{CO}_{2}$. Because of wheat straw's low digestibility, enteric $\mathrm{CH}_{4}$ production is an important problem but no significant effect of CT in wheat strawbased feeding was observed in our study, and the effects of $\mathrm{CT}$ on rumen $\mathrm{CH}_{4}$ emissions were not clear. The CT generally form complex bonds with ruminal cellulose and reduce hydrogen utilization for methanogenesis (Pinerio-Vazqueza et al., 2015).

It is likely that a reduction in WS concentration, the source of cellulose, in the PP and $\mathrm{PH}$ groups may have caused the current effect to be hidden. The average daily $\mathrm{CH}_{4}$ production per animal was $33.5 \mathrm{~g}$ over all groups, corresponding to annual $\mathrm{CH}_{4}$ emission of $12.2 \mathrm{~kg}$ per animal. Broucek (2014) found that milk sheep produce $8.4 \mathrm{~kg}$ of $\mathrm{CH}_{4}$ per animal annually, which is lower than that obtained in our study. The difference can be attributed to different breeds used between the studies.

The $\mathrm{CO}_{2}$ detected may be of both enteric and respiratory origin. The CT can also increase the content of glycoprotein in saliva and stimulate saliva production (Gxasheka et al., 2015). This result shows that high saponin and CT feeds must be chewed more thus, more $\mathrm{O}_{2}$ consumption and $\mathrm{CO}_{2}$ production may have occurred in the $\mathrm{PP}$ and $\mathrm{PH}$ groups. El Meccawi et al. (2008) found that alfalfa of higher CT content was more effective than Acacia in producing body heat. Heat production is an important trigger of high $\mathrm{O}_{2}$ consumption and $\mathrm{CO}_{2}$ production in the body.

The $\mathrm{N}_{2} \mathrm{O}$ was not of enteric but fecal origin and may be related to possible accumulation of feces in the environment. Every animal kept in the room for $24 \mathrm{~h}$ was left with its own external feces. According to this, daily $\mathrm{N}_{2} \mathrm{O}$ release per sheep tended to be lower $(\mathrm{P}=0.05)$ in the group receiving $\mathrm{PH}$ (Fig. 4). Addition of $\mathrm{PP}$ and $\mathrm{PH}$ 
significantly decreased daily $\mathrm{N}_{2} \mathrm{O}$ production for $\mathrm{kg}$ feed consumption. In this study, $\mathrm{CO}_{2}$ emission increased in $\mathrm{PP}$ and $\mathrm{PH}$ groups but decreased $\mathrm{N}_{2} \mathrm{O}$. The global warming potential of $\mathrm{N}_{2} \mathrm{O}$ is 298 times stronger than $\mathrm{CO}_{2}$ and is a greenhouse gas that emerges in animal activities (IPCC, 2007).

The results were promising in terms of nitrogen-based gases. The $\mathrm{N}_{2} \mathrm{O}$ production tended to decrease in the $\mathrm{PH}$ groups per sheep (Table 5) and we had strong indications that $\mathrm{N}_{2} \mathrm{O}$ release was related to protein metabolism associated with CT in the rumen and the intestine. We speculate that the lower emissions were due to the lower $\mathrm{N}$ content of the feces as a result of greater $\mathrm{N}$ binding and inhibition of $\mathrm{N}$ transformation. According to Bunglavan and Dutta (2013), 2\%-3\% CT in the diet may reduce ruminal protein degradation and result in degradation of the tannin-protein complex in the abomasum, and its lower $\mathrm{pH}(<3.5)$ may increase the absorption of amino acids in the intestine.

The CT concentration was up to $1 \%$ in the PP and PH groups in our study. The results suggested that $\mathrm{CT}$ in $\mathrm{PH}$ might affect fecal composition by binding proteins in the rumen and so improving protein digestion in the small intestine. The lower emissions from $\mathrm{PH}$ were also probably due to the lower contents of mineral $\mathrm{N}$ in the manure/feces. An important source of $\mathrm{N}_{2} \mathrm{O}$ in feces is ammonia-based nitrogen and it is known that $\mathrm{CT}$ decreases ruminal protein dissolution and decreases ammonia concentration. This increases the non-ammonia nitrogen flow in the small intestine (Choi et al., 2012; Naumann et al., 2017).

\section{Conclusion}

We found that the use of CT-containing PP and PH feed as half of the wheat straw as roughage feed (WS was $10 \%$ in the current study) was a good choice for lamb fattening and production. The $\mathrm{CO}_{2}$ emissions significantly increased in the $\mathrm{PP}$ and $\mathrm{PH}$ groups, but they did not effectively reduce the production of enteric $\mathrm{CH}_{4}$ in the rumen and energy loss through $\mathrm{CH}_{4}$ for the WS-based feed.

There is significant potential for $\mathrm{PH}$ in the fecal emission of nitrogen-based gases. We speculate that the lower emissions were due to the lower $\mathrm{N}$ content of the manure as a result of greater $\mathrm{N}$ binding and inhibition of $\mathrm{N}$ transformation. Thus, some byproducts of the food industry have a potential as animal feeds that can reduce $\mathrm{N}_{2} \mathrm{O}$ emissions. Reducing the emissions of GHG from ruminants can put such by-products to better use and help in mitigating the adverse impacts of climate change at the same time.

\section{REFERENCES}

[1] Abarghuei, M. J., Rouzbehan, Y., Salem, A. Z. M., Zamiri, M. J. (2013): Nutrient digestion, ruminal fermentation and performance of dairy cows fed pomegranate peel extract. - Livestock Science 157: 452-461.

[2] Adams, L. S., Seeram, N. P., Aggarwal, B. B. (2006): Pomegranate juice, total pomegranate ellagitannins, and punicalagin suppress inflammatory cell signaling in colon cancer cells. - Journal of Agricultural Food Chemistry 54: 980-985.

[3] Addisu, S. (2016): Effect of dietary tannin source feeds on ruminal fermentation and production of cattle; a review. - Online Journal of Animal and Feed Research 6(2): 4556. 
[4] AOAC. Association of Official Analytical Chemistry. (1998): Official methods of analysis 16th ed. - AOAC International. Washington DC. USA.

[5] Barry, T. N., McNabb, W. C. (1999): The implications of condensed tannins on the nutritive value of temperate forages fed to ruminants. - British Journal of Nutrition 81: 263-272.

[6] Bhatta, R., Shinde, A. K., Vaithiyanathan, S., Sankhyan, S. K., Verma. D. L. (2002): Effect of polyethylene glycol-6000 on nutrient intake, digestion and growth of kids browsing Prosopis cineraria. - Animal Feed Science and Technology 101: 45-54.

[7] Broucek, J. (2014): Production of Methane Emissions from Ruminant Husbandry: A Review. - Journal of Environmental Protection and Ecology 5: 1482-1493.

[8] Bunglavan, S. J., Dutta, N. (2013): Use of Tannins as Organic Protectants of Proteins in Digestion of Ruminants. - Livestock Science 4: 67-77.

[9] Choi, C. W., Kim, K. H., Chang, S. S., Choi N. J. (2012): Soluble Non-ammonia Nitrogen in Ruminal and Omasal Digesta of Korean Native Steers Supplemented with Soluble Proteins. - Asian-Australasian Journal Animal Science 25: 1269-1275.

[10] El-Meccawi, S., Kam, M., Brosh, A., Degen, A. A. (2008): Heat production and energy balance of sheep and goats fed sole diets of Acacia saligna and Medicago sativa. - Small Ruminant Research 75: 199-203.

[11] Ghaffari, M. H., Tahmasbi, A. M., Khorvash, M., Naserian, A. A., Vakili, A. R. (2014): Effects of pistachio by-products in replacement of alfalfa hay on ruminal fermentation, blood metabolites, and milk fatty acid composition in Saanen dairy goats fed a diet containing fish oil. - Journal Applied Animal Research 42: 186-193.

[12] Gxasheka, M., Tyasi, T. L., Qin, N., Lyu, Z. C. (2015): An overview of tannins rich plants as alternative supplementation on ruminant animals: A Review. - International Journal of Agricultural Research and Review 3: 343-349.

[13] IPCC. Intergovernmental Panel on Climate Change. (2007): Changes in atmospheric constituents and in radiative forcing. In: Climate Change 2007: The Physical Science Basis. - Contribution ofWorking Group I to the Fourth Assessment Report of the Intergovernmental Panel on Climate Change. Cambridge University Press, Cambridge, UK and New York (Chapter 2).

[14] Jayaprakasha, G. K., Negi, P. S., Jena, B. S. (2006): Antimicrobial activities of pomegranate. - In: Heber, D., Schulman, R. N., Seeram, N. P. (eds.) Pomegranates: Ancient Rootsto Modern Medicine Seeram. CRC Press, Taylor \& Francis Group, Boca Raton, FL, USA. p 3-29.

[15] Karaogul, E. (2011): Extraction and HPLC characterization of some oak species (Quercus) roots. - Doctoral Thesis. University of K. Sutcu Imam. K.Maraş, Turkey.

[16] Kotsampasi, B., Christodoulou, V., Zotos, A. (2014): Effects of dietary pomegranate byproduct silage supplementation on performance, carcass characteristics and meat quality of growing lambs. - Animal Feed Science and Technology 197: 92-102.

[17] Makkar, H. P. S., Blummel, M., Becker, K. (1995): Formation of complexes between polyvinyl pyrrolidones or polyethylene glycols and their implication in gas production and true digestibility in vitro techniques. - British Journal of Nutrition 73: 897-913.

[18] Naumann, H. D., Tedeschi, L. O., Wayne, E. Z., Nichole, F. H. (2017): The role of condensed tannins in ruminant animal production: advances, limitations and future directions. - Revista Brasileira de Zootecnia 46: 929-949.

[19] Norouzian, M. A., Ghiasi S. E. (2012): Carcass Performance And Meat Mineral Content In Balouchi Lamb Fed Pistachio By-Products. - Meat Science 92: 157-159.

[20] Petrucci, R. H., Herring, G., Madura, J., Bissonnette, C. (2010): General Chemistry: Princples and modern applications with mastering chemistry. - 10th ed. Published by Pearson. Canada.

[21] Piñeiro-Vázqueza, A. T., Canul-Solísa, J. R., Alayón-Gamboab, J. A., Chay-Canulc, A. J., Ayala-Burgosa, A. J., Aguilar-Péreza, C. F., Solorio-Sáncheza, F. J., Ku-Veraa, J. C. 


$$
\text { - } 316 \text { - }
$$

(2015): Potential of condensed tannins for the reduction of emissions of enteric methane and their effect on ruminant productivity. - Archivos de Medicina Veterinaria 47: 263272.

[22] Provenza, F. D. (1995): Post ingestive feedback as an elementary determinant of food preference and intake in ruminants. - Journal of Range Management 48: 2-17.

[23] Sadq, S. M., Ramzi, D. O. M., Hamasalim, H. K., Ahmed, K. A. (2016): Growth Performance and Digestibility in Karadi Lambs Receiving Different Levels of Pomegranate Peels. - Open Journal of Animal Sciences 6: 16-23.

[24] Shabtay, A., Eitam, H., Tadmor, Y. (2008): Nutritive and antioxidative potential of fresh and stored pomegranate industrial byproduct as novel beef cattle feed. - Journal of Agricultural Food Chemistry 56: 10063-10070.

[25] Shakeri, P., Riasi, A., Alikhani, M. (2013): Effects of feding pistachioby-products silage on growth performance, serum metabolite sandurine characteristics in Holstein male calves. - Journal of Animal Physiology and Animal Nutrition 97: 1022-1029.

[26] Shakeri, P., Riasi, A., Alikhani, M. (2014): Effects of long period feding pistachio byproduct silage on chewing activity, nutrient digestibility and ruminal fermentation parameters of Holstein male calves. - Animal 8: 1826-1831.

[27] TUIK. (2015): Turkish Statistical Institute. Crop production statistics in Turkey. Available at: <http://tuik.gov.tr.>Accessed on: Feb. 7, 2017.

[28] TUIK. (2016): Turkish Statistical Institute. Crop production statistics in Turkey. Available at: <http://www.tuik.gov.tr/PreTablo.do?alt_id=1001.> Accessed on: June 28, 2016.

[29] Van Soest, P. J., Robertson, J. B., Lewis, B. A. (1991): Methods for dietary fiber, neutral detergent fiber and nonstarch polysaccharides in relation to animal nutrition. - Journal of Dairy Science 74:583-597.

[30] Villalba, J. J., Provenza, F. D. (2000): Postingestive feedback from starch influences the ingestive behaviour of sheep consuming wheat straw. - Applied Animal Behaviour Science 66: 49-63.

[31] Zarei, M. (2013): Pomegranate by product (Punica granatum L.) in Animal Nutrition. International Journal of Research and Reviews in Pharmacy and Applied Science 3: 685698. 